\title{
IN VITRO ANTAGONISTIC POTENTIAL OF Trichoderma spp. AGAINST Colletotrichum gloeosporioides AGENT OF ANTHRACNOSE IN THE PASSION FRUIT (Passiflora)
}

\author{
(Potencial antagónico in vitro de Trichoderma spp. \\ sobre Colletotrichum gloeosporioides agente de la antracnosis \\ en Pasionaria (Passiflora))
}

José de Ribamar de Sousa Rocha ${ }^{1 *}$, Neiva Tinti de Oliveira²

'Departamento de Biologia - Universidade Federal do Piaú,

CCN, 64.049-550, Teresina, PI, Brasil.

${ }^{2}$ Departamento de Micologia - Universidade Federal de Pernambuco,

CCB, 50.670-420, Recife. PE, Brasil.

Palabras clave:Colletotrichum gloeosporioides, Trichoderma spp..control biológico, antracnosis, pasionaria. Key words: Colletotrichum glocosporioides, Trichoderma spp., biocontrol, anthracnose, passion fruit.

\section{RESUMEN}

Diecisicte cepas de Trichoderma aisladas del suelo de plantaciones de pasionaria, fueron seleccionadas por su tasa de crecimiento y capacidad de exporulación, evaluándose su potencial antagónico sobre un aislamiento de C. glocosporioides, agente de la antracnosis de la pasionaria. Mecliante la unilización de la técnica de cultivos apareades se comprobio que todas las cepas de Trichoderma causaron alteraciones morfofisiológicas en las hifas del fitopatiogeno. Este tipo de actividad fire evidenciado por plasmolisis, vacuolización y enroscamiento de hifas. Lin 13 apareannientos hubo sobreposición de Trichoderma sp., causando inhibición del crecimiento micelial de las colonias del fitopatógeno, no sobreviviendo este en 10 apareamientos. De las tres especies evaluadas, T. koningii reunió el mavor numero de aislamientos con caracteristicas favorables para su utilización en el control biologgico de C. glocosporioides, to que sugiere la posibilidad de controlar la antracmosis de esta planta en el campo.

\section{INTRODUCTION}

Passion-fruit is subject to be allacked by various discases and pests so to fight against them the șistematic use of defensive means is necessary. This musi be done,

\section{SUMMARY}

Seventeen strains of Trichoderma isolated from a soil planted with passion fruits were selected because of its rate of growth and sporulation ability, their antagonistic polential against an isolate of C.glocosporioides, an agent causing anthracnose in passion fruit, being evaluated. By means of the paired culture technique it could be seen that all the Trichoderma strains induced morphophysiological alterations in the phvtopathogen hyphae. This kind of phenomenon became apparent through plasmolvisis, vacuolization and coiling of hyphae. An overlapping of Trichoderma occurred in thirteen pairings what inhibited the micelial growth of the phytopathogen colonies and caused death of the latter in 10 pairing. Of the three species examined, T. koningii exhibited the highest number of isolates meeting the desirable requirements in order to perform the biocontrol of C. glocosporioides, meaning that there is a chance to comtrol anthracmose of this plant in the field.

howercr. using strict critcria. since, to guarantee its fertilisation. the plant needs the action of pollinising insects (4.3).

Passion-fruit anthracnose has Colletotrichium gloeosporioides (Penz..) Penz. \& Saccardo as ethiological agent. The disease attacks all the organs of the aerial part

"Part of disscrtation to obtain a Msc degrec in Biology of Fungi at the UFPE. Brazil. 
of the plant. It occurs in all orchards throughout Brazil and its controll is sometimes very difficult when climatic conditions favour it (49).

In order that passion-fruil can receive the greatest market approval, in addition to adequate packaging. transport and conservation. the fruit must be presented in a well-matured state, with a smooth pecl. and free of anthracnose (23). The control of the passion-fruit anthracnose, is made basically by means of the application of preventive fungicides $(32,37)$. The fungicides may promote an increase in the incidence of discases due to the interference and death of antagonists or because of the action on the bencficial microbiota (27).

The research for alternative strategies to the use of chemical products used in the control of plant diseases, continues as a long-term goal of rescarch in agriculture. Biological methods to reduce discase levels already exist in many traditional handling techniques and storage processes. What is usually absent, however, is a detailed understanding of the microbial ccology which forms the base of this natural method of suppression. This information is essential so that, the antagonistic interactions which occur between the saprophytic microbiota and the invading fungus which causcs the discase in the plant can be explored (29). This natural method is known as biological control and can be defined as the occurrence of antagonistic interactions between pathogenic and nonpathogenic organisms which result in the suppression or control of the pathogenic organisms, by climinating or decreasing their effects on the hosts.

The use of microorganisms as a recognised antagonistic ability and non-resident in the phyloplan is also a common technique in the biological control of discases in the acrial portion (8). Among the potential agents of biocontrol, the Trichoderma Pers. has been one of the most studied, considering its peculiar antagonistic characteristics in natural conditions, mainly in the soil (5. $13,24,34,42)$. Another adrantage, of being a biocontrol agent is the fact that the Trichoderma species rapidly become resistant to fungicides when exposed to them. Resistant strains, antagonistic to a particular pathogen, may be used together with fungicides for the control of other discases $(1,26,34,47)$.

The natural occurrence of Trichoderma. in commercial passion-fruit plantations in Brazil, has al ready been cited (36). and it has also been isolated from the root and stem of this plant (31). C. gloeosporioides, isolated from the leaves of the cashew tree, showed high sensitivity to Trichoderma which behaved as a promising agent in the control of this important pathogen under laboratory conditions (33).

Bccause of Trichoderma's antagonistic potentiality in the biological control of C. gloeesporioides, it has become necessary to come to know its antagonistic behaviour and to verify the possibility of using it in the biological control of the passion fruit anthracnose. This study has been developed with the objective of selecting isolates of Trichoderma with a better antagonistic activities over C.glocosporioides, by means of the study of in vitro antagonistic interactions.

\section{MATERIALS AND METHODS}

A high pathogenic isolate of C.glocosporioides, obtaincd from a passion-fruit plant, 41 isolates of Trichoderma obtained from soils of passion-fruit plantations, and 2 isolates of Trichoderma (TR2 and T25) obtaincd from URM-UFPE), in the State of Pernambuco, Brazil, were eraluated in the tests.

Mycelial growth rate and capacity of sporulation. To characterize the isolates as to their mycelial growth rate and capacity of sporulation, cultures were made in PDA (potato-dextrose-agar) medium, transfering $4 \mathrm{~mm} /$ diameter discs of mycelia-agar. with 3 day incubation withdrawn from the edge of the cultures, in to the centre of Petri dishes with PDA in triplicate. These were incubated at $26^{\circ} \mathrm{C}$.

To evaluate the mycelial growth, daily measurements were made of the diameter of the colonies in two diametrically opposed directions. until the moment when the entire surface of the culture medium was colonised by the fungi, in any one of the repetitions used. To calculate the linear rate of growth of the mycelium the formula described by Lilly \& Barnet was used (30).

The capacity of sporulation was visually cstimated, after 10 days of incubation. The sporulation was classified as "abundant" when the sporulation was very visible all across the surface of the colony; average "medium" when the sporulation was visible in an area corresponding to about half the surface of the colony; and "sparse" when the sporulation was visible on lesser than half the surface of the colony.

Antagonism test. The antagonists which had the greatest rate of mycelial growth and sporulation were grown in paired culture with the phytopathogen under the method described by Dennis \& Webster (18). Initially, the C. glocosporioides isolate was innoculated on $9 \mathrm{~cm} / \mathrm{diam}$. Petri dishes, with PDA and incubated for 6 days at $26^{\circ} \mathrm{C}$. After this period. $4 \mathrm{~mm}$ diameter dises of mycelia-agar were removed from the edges of the colonies where growth was vigorous, and transferred into Petri dishes with PDA. One disc of mycelial-igar was placed about $1 \mathrm{~cm}$ from the edge of each Petri dish and incubated for 3 days at $26^{\circ} \mathrm{C}$.

After incubation, a disc of mycelia-agar of 
Trichoderma, removed from the colony edge after being incubated for 3 days was transferred in to the opposite side of the Petri dish. about $1 \mathrm{~cm}$ from the edge. in a position diametrically opposed to that which had been occupied by the disc of mycelia-agar of $C$. glocesporioides. The dishes. with the wo discs $7 \mathrm{~cm}$ apart from each other, were incubated at $26^{\circ} \mathrm{C}$. with three repelitions. The measures of the daily mycelial growth of the colonies one towards the other were noted. Their mecting. the inhibition of mycelial growth and the orcrlapping of the colonics were observed. The isolates were classified according to their antagonism agrecing with Bell et al. 's scale. (6).

Antagonic interactions. For studies of the antagonic interactions between hyphac of the antagonists and phỵtopathogen. paired cultures were made and corer slip placed in the central region of the Petri dishes. where the mecting of the colonies would take place. After the mecting . the cover slip were withdrawn and placed on a glass lamina for microscopy with a drop of Amann's blue colouring. Thereafter they were observed under an optical microscope and the occurred interactions among the hy phac were analysed.

Survival of C.gloesporioides. The survival of the phytopathogen. after paired culture. was verified through observation of the derelopment of the colonies begimning with mycelia-agar. $+\mathrm{mm}$ in diameler. removed from the colony of the phystopathogen in the zone of the antagonism. at a distance of $2 \mathrm{~cm}$ from the line of initial contact between the colonies. Fise discs of mycelial-agill were transferred to Petri dishes with PDA medium and incubated at $26^{\circ} \mathrm{C}$, with three repetitions, as a modification of the Icchnique described by Tronsmo \& Demnis (t+).The analysis of the survival of the phytopathogen was carried out after $1+$ days of incubation by observing the number of colonies that had been formed.

\section{RESULTS AND DISCUSSION}

Data about the arerage of mycelium growth rate and sporulation capacity of the isolites of Trichoderma are showed in Table l. The isolates Ti1. Ti2. Ti.3. Ti5. Ti8. Ti9. Tilo. Til3. Til5. Til7. Til8. Tily. Ti25, Ti26. Ti35. TR-2 and T-25. presented mycelimm growth rates greater than the average rate with "abundant" or "arerage" sporulation and were selected for the antagonism test in paired cultures. The mycelial growth rate of the phytopathogen was. approximately. twice lessed than the arcrage mycelial growth rate of the antagonists. $C$. glocosporioides was inoculated three dạs carlier so that the mecting of the colonies could occur in the centre of the Petri dish. The mycelial growth rate of the antagonists affects their interactions with other fungi (25). It was observed that the isolates of Trichoderma which presented the greatest speed of mycelial growth showed greater antagonistic potential over C. glocosporioides (33). The rapid mycelial growth winning the competition for nutrients and the rapid colonization of the substract. associated with the production capacity of a large number of spores for dispersion, are factors which. when added to a promisingantagonistic potential, determine that an isolate has characteristics of being a good biocontroller (14).

Table 1. - Mycelial growth rate and sporulation of the strains of $C$. glocosporioides (Cg) and of Trichoderma (Ti), in PDA medium at $26^{\circ} \mathrm{C}$.

\begin{tabular}{|c|c|c|c|}
\hline \multirow{2}{*}{$\begin{array}{l}\text { Isolate } \\
\mathrm{Cg} 3\end{array}$} & Specie & ale $(\mathrm{mm}$ & \multirow{2}{*}{$\frac{\text { Sporulation }}{\text { Abundiant }}$} \\
\hline & $C:$ glocessporivides & 14,88 & \\
\hline Til & T. harzicumum & 24.48 & Medium \\
\hline $\mathrm{Ti} 2$ & T. koningil & 24.62 & Abundant \\
\hline $\mathrm{Ti} 3$ & T. harriarmum & 46.87 & Mćdium \\
\hline lit & T. komingii & 8.54 & Sparse \\
\hline Ti5 & T. harzianum & 40,46 & Medium \\
\hline lï & T. har-ianmum & 15,43 & Sparse \\
\hline $11 i 7$ & T. har-iarmum & 17,42 & Sparse \\
\hline lis & T. contreosiricle & 41.35 & Medium \\
\hline Ti9 & T. antreorivicle & 43,82 & Abundint \\
\hline liilo & T. anreoriricle & 46,87 & Madium \\
\hline liil & T. anreoviricte & 16.68 & Medium \\
\hline liil2 & T. antreosiricle & 15.26 & Medium \\
\hline liil.3 & T. cureoviride & 42.24 & Medium \\
\hline $11 i 14$ & T. harzianum & 9.91 & Medium \\
\hline liils & T. her:iammm & 42.24 & Abundant \\
\hline 91316 & T. konningii & 14.78 & Medium \\
\hline $11 i 17$ & T. konmingii & 39.60 & Mledium \\
\hline liils & T. hicuzicinum & 39. 43 & Medium \\
\hline lile & T. anueosircle & 48.86 & Abundant \\
\hline 17320 & T. kommgii & 13,44 & Sparsc \\
\hline 1121 & T. komingii & 9.91 & Medium \\
\hline 11322 & T. koningii & 15.90 & Medium \\
\hline $11 i 23$ & T. harzicinnum & 9.91 & Medium \\
\hline $17 i 24$ & T. harzicunum & 11,19 & Medium \\
\hline $17 i 25$ & T. koningii & 40.15 & Medium \\
\hline Ti26 & T. koningii & 39.74 & Medium \\
\hline Ti2 27 & T. koningii & 19.20 & Medium \\
\hline 1128 & T. harzicuntum & 10.56 & Medium \\
\hline Ti29 & T. anreosiricle & 12.24 & Abundant \\
\hline 1i30 & T. antreosiricle & 14.79 & Medium \\
\hline 113.31 & T. anreosiricle & 17,42 & Medium \\
\hline 113.32 & T. koningii & 19.20 & Abundint \\
\hline Ti33 & T. koningii & 8.54 & Abundant \\
\hline 1134 & T. anteosiricle & 17.42 & Medium \\
\hline Ti35 & T. anressiricle & 39.98 & Medium \\
\hline Ti.36 & T. anreovirde & 17.91 & Abundiant \\
\hline Tii37 & T. kemingu & 12.87 & Medium \\
\hline Tii38 & T. koningi & 9.91 & Abundint \\
\hline Ti39 & T. komm!gii & 15.43 & Medium \\
\hline lit() & T. kemingu & 19.20 & Medium \\
\hline $1 \ddot{i}+1$ & T. komingii & $19,(03$ & Sparse \\
\hline TR-2 & T. viricle & 32.95 & Abundant \\
\hline $19-25$ & T. harzicumm & 41.12 & Abundiant \\
\hline \multicolumn{4}{|c|}{ 1) Arerage of three repetition. } \\
\hline \multicolumn{4}{|c|}{ 2) Vistal saluation altor lo days of incubation. } \\
\hline
\end{tabular}

In the pairing of the cultures, after the meeting of the colonics. orerlapping occurred. The measures of these are showed in Table 2. The antagonistic bchaviour of the 
isolates was very diverse. The paired colonies were found after 48 hours of incubation. except for the two isolates TR-2 and T-25, which found the colony of the phỵtopathogen after 72 hours. The Ti 17 isolate was the one that orergrew most rapidly the plytopathogen after 72 hours. The Ti 19 isolate which had the grealest micelial growth ratc. started overlapping only after 72 hours. while the Ti 2 of least mycelial growth began overlapping before 72 hours. The Ti 10 and Ti 26 isolates of high mycelial growth rates did not overgrew the phytopathogen colonics. The Ti2. Ti 17. T-25 isolates completly overgrew the colonics of C. gloesporioides, wilh $1+t$ h of incubation. After mecting of the colonies. there was an inhibition of the mycelial growth of the plỵtopathogen. in all the pairings. The varied antagonistic behaviour reflects the action of sereral antagonism mechanisms. Various lypes of antagonistic interactions used bythe fungi were observed and they are detailed in Table 2.

Sporulation of the antagonistic occurred on the phytopathogen. generally in compact masses of conidia. The Ti 8. Ti 13. Ti 17. Ti 25. and T-25 isolates produced "abundant" sporulation on the phỵtopathogen. but the Ti 35 isolate. which overlapped the phytopathogen colony after some delay did not sporulate. The sporulation of the phỵtopathogen decreased and was "sparse" in 10 pairings. while "medium"sporulation of the phytopathogen occurred. eren on the colony of antagonists. in the paired cultures wilh Ti 3. Ti 9. Ti 13. Ti IS. Ti 19. Ti .35 and TR2 isolates.

The last columun of Table 2 presents the classification results of the isolates as 10 antigonism based on the overlapping of the colonics and in accordance with Bell et al. (6). The Ti 2. Ti 17. TR-2 and T-25 isolates presented the greatest overlapping and were placed in class 1: most isolates were placed in class 2: the Ti 10 and Ti 26 isolates in class 3: and no isolates in classes + and 5.

Orergrowth on the phytopathogen colony is an advantageous characteristic of the antagonists in the dispute for the colonized area. wimning the competition for space and nutrition. This is one of the ways of exercising biocontrol on the other organism which has its growth reduced or paralysed ( 18 ). The inhibition of mycelial growth and decrease of the sporulation of the phytopathogen colony is another important antagonistic characeristic exercised by the Trichoderma isolates. These are capable of producing antibiotics. besides ensines and olher toxic products which may interlere in the deve-lopment of the phỵlopathogen. inducing an undesirable condition for growth and sporulation (9. 1(), 11, 28, 35. 46).

The interactions that occured between the hyphac are shown in Table 3. All the Trichoderma isolates affected the Ceglocosporioides through various types of antagonistic interactions. including those which do not catuse orerlapping. suggesting that there are mechanisms of biocontrol for antibiosis. competition and micoparasitism. The plamolysis of hyphac occurred in almost all paired cultures. except on Ti 2. Vacuolation was erident in many cells. which also showed a granulous aspect of the protoplasm withoul existing. howerer. a disintegration of the cellwall. In m any cases the Trichoderma species can be classified as necrotrolic micoparasites. for they kill the host. and make use of the nutricnts spilling from the dead hypla (t. 1t).

In mycoparasitism. the hypha of the host may primarily suffer action of toxic metabolic products. including en\%mes. before disorganization and dead occur $(35)$.

Table 2. - Orergrow of the Trichoderma and classification of the antagonism.

\begin{tabular}{|c|c|c|c|c|c|}
\hline \multirow[b]{2}{*}{ Trichoderma } & \multicolumn{4}{|c|}{ Orergrow (cm $)^{\prime}$} & \multirow[b]{2}{*}{$\begin{array}{l}\text { Class of } \\
\text { antag. }^{2}\end{array}$} \\
\hline & $72 h$ & $96 \mathrm{~h}$ & $12(1) 1$ & $I+4 h$ & \\
\hline Til & - & - & 1.50 & $2.75 \mathrm{Mc}^{*}$ & 2 \\
\hline Ti2 & 0.80 & 1.80 & $3 .+5$ & +.5() $\mathrm{Ab}$ & 1 \\
\hline Ti.3 & - & 1.8() & 2.45 & 2.9) Mc & 2 \\
\hline Ti5 & - & 1.22 & 2.66 & $2.80 \mathrm{Mc}$ & 2 \\
\hline Tis & 0.73 & 1.57 & 2.80 & $3.60 \mathrm{Mc}$ & 2 \\
\hline Til) & - & 0.86 & 1.10 & $2.75 \mathrm{Ab}$ & 2 \\
\hline Till & - & - & - & - $M c$ & 3 \\
\hline Til.3 & $(0.9()$ & 1.80 & 2.8() & $3.70 \mathrm{Mc}$ & 2 \\
\hline Tils & - & - & 1.8 .3 & $2.85 \mathrm{Ab}$ & 2 \\
\hline Til7 & 2.10 & 2.57 & $3.5+$ & $+.50 \mathrm{Mc}$ & 1 \\
\hline Tils & - & - & 0.9() & $2.21 \mathrm{Mc}$ & 2 \\
\hline Tily & - & 1.12 & 2.53 & $3.10 \mathrm{Ab}$ & 2 \\
\hline $\operatorname{Ti} 25$ & $(1.75$ & 1.61 & 3.20 & $3.67 \mathrm{Mc}$ & 2 \\
\hline $\operatorname{Ti26}$ & - & - & - & $\mathrm{Mc}$ & 3 \\
\hline Ti.j. & - & - & - & $1.93 \mathrm{Mc}$ & 2 \\
\hline TR2 & - & - & 1.13 & $2.75 \mathrm{Ab}$ & 2 \\
\hline $\mathrm{T}-25$ & - & 2.50 & 3.20 & +.5() $\mathrm{Ab}$ & 1 \\
\hline
\end{tabular}

$* \mathrm{Mc}=$ Meditum Sporulation. $\mathrm{Ab}=$ Abundant

1) Arerage of three repelitions.

2) Bell e' al. 's scale of classes of antagonism (6): 1= Trichoderma completcly overgrew the pathogen and corered the entire medium surfice: 2 = Trichederma overgrew al least 1 wo-thirds of the medium surface: and $3=$ Trichoderma and the pallogen each colonized approximalely one-half of the medium surface and neither organismappeated to dominate the other: $t=$ The pathogen colonized at least wo-lhirds of the medium surface and appeared to withstand encroachment by Trichoderma and $\bar{s}=$ The pathogen completely overgrew the Trichoderma and occupied the entire medium surface. 
Table 3.- Antagonistic interactions between hyphae of Trichoderma (Ti) and Colletotrichum gloeosporioides strains.

\begin{tabular}{|c|c|c|c|c|c|c|c|c|c|}
\hline \multirow[b]{2}{*}{ Interaction } & \multicolumn{8}{|c|}{ Strains } & \multirow[b]{2}{*}{ Til5 } \\
\hline & Til & $\mathrm{Ti} 2$ & Ti3 & Ti5 & Ti8 & Ti9 & Tilo & Til3 & \\
\hline Plasmolysis of hyphac & + & - & + & + & + & + & + & + & + \\
\hline Vacuolation of hyphac & + & + & + & - & - & + & - & + & + \\
\hline Parallel growth of hyphac & + & + & + & + & + & - & + & + & + \\
\hline Penctration of hyphac & - & + & + & - & - & + & - & - & - \\
\hline Deformation of apressoria $\mathrm{Cg}$. & - & + & - & - & - & - & + & - & - \\
\hline Hook-hyphac of $\mathrm{Ti}$ & - & + & - & + & + & + & - & + & + \\
\hline Fragmentation of hyphac $\mathrm{Cg}$ & - & - & + & + & - & - & - & - & - \\
\hline Rings of lıpphac Ti & - & - & - & + & - & + & + & + & - \\
\hline \multirow[t]{2}{*}{ Coiling of hyphac } & + & + & + & + & + & + & + & + & + \\
\hline & Til 7 & Til 8 & Til9 & Ti25 & Ti26 & Ti35 & TR2 & $\mathrm{T}-25$ & \\
\hline Plasmolysis of hyphac & + & + & + & + & + & + & + & + & \\
\hline Vacuolation of lypplate & - & + & + & + & + & + & + & + & \\
\hline Parallel growth of hyphac & + & + & + & + & + & + & + & + & \\
\hline Penctration of hyphac & - & - & - & - & + & - & - & + & \\
\hline Deformation of apressoria $\mathrm{Cg}$ & + & - & - & - & + & + & - & + & \\
\hline Hook-hyphac of Ti & + & + & + & - & + & + & - & + & \\
\hline Fragmentation of hỵphac $\mathrm{Cg}$ & - & - & + & - & - & - & - & - & \\
\hline Rings of hyplac Ti & - & + & + & + & - & - & - & - & \\
\hline Coiling of hyphac & + & + & + & + & + & + & + & + & \\
\hline
\end{tabular}

$(+)=$ presence: $(-)=$ absence .

The coiling of the segments of hyphac with thickening of cell walls in the phy topat hogen was observed in somes cases. The parallel growth of the hyphac. common in Trichoderma culturc. occurred very offen in paired cultures and only the Ti 19 isolate did not present parallel growth of hyphac. The penetration into hyphic of phytopathogen occurred with Ti 2. Ti 3. Ti9 and Ti 26 isolates and. apparently. after desintegration of the protoplast. the cell wall remained intact.

The deformation of the apresseria of the phytopathogen was induced by the Ti2. Ti 10. Ti17. Ti26. Ti 35 and T-25 isolates. which made them longer and more slender.

Appresseria is essential for the infection of $C$. glocosporioides, the chief function of the apressoria is direct penetration into the host (22). Deformation, probably. makes complete derelopment diflicult and limits the performance of the apressorta in the infection process of the phytopathogen. in the tissuc of the host. The occurrence of short hyphac around the phytopathogen. which was similar to hatustorica was observed. but the function of these struclures. which are called hook-hyphae. cannot be certainly prosed with assurance. The fragmentation of pleytopithogen hephac was observed with Ti 3. Ti 5. Ti 17 and Ti 19 isolates. Some isolates (Ti ). Ti 10. Ti 1.3 and Ti 19) of T.auresoviride and the isolate (Ti 18) of T. harziamum. formed characteristic rings of hyphae. Elad et al. (21). observed the same phenomenon and associated it 
with parasitism of $R$. solani by T. harzianum. for they formed hyphac rings in the interaction zone and they belicied that there was not any cexplanation for the rolc of these structures in their life cycle and that they were related to micoparasitism. for they were not produced by T. aureoviride nor by T. harzianum in the absence of host mycelium. It was observed that. eren in the absence of host mycelium. there was ring formation. suggesting that their formation was not directly related to mycoparasitism. When Trichoderma hyphac showed themselves to be in vigorous growth. thicker and less sinuous than the other mycelium ones. hyperparasitism through direct contact with phytopathogen hyphac did not occur. Contact between the hyphac of the fungi determined coiling at various points and at different intensitics. Pariallel growth and coiling of hyphac are cited by various authors as the most common antagonistic interactions. which later make possible the manifestation of the ones (9. 18, 21. 4t. 47). C. glocosporioides conidia did not become parasites.

Table +. shows the survival data of the $C$. glocosporioides after 7 days in paired culture with Trichoderma. Mycelia-agar dises of the antagonistic phytopathogen were incubated for It days on Petri dishes with PDA. After incubaling for 7 days some isolates permitted the survival of the phytopathogen to $100 \%$. The Ti 9 and Ti 18 isolates. permilted only $40 \%$ and $20 \%$. respectively, but after incubating for I t dilys. they permitted $100 \%$ survival. In the remaining isolates Ti I. Ti 8 . Ti 15. Ti 19. Ti 25. TR2 and T-25 isolates. there was no survival of the phytopathogen. In the cases in which there was no survival of $C$. glocosporioides from the beginning of incubation. it is possible that a fungicidal effect has occurred. caused by the antagonist in through the release of diffusible antibiotics in the medium (16. 17). In cases where survival occurred. with revival of phytopathogen colonies after a few days of incubation. a fungistattic effect may have occurred. in which. after the action of the antagonists stopped. the phytopathogen recorered its growth and sporulation capacity.

The results indicate that isolates of Trichederma. in in vitro tests. in rclation to its antagonistic capacity to C.gloeosporioides. in general. showed themselies to be promising in the biocont rol of the ant haranose agent of the passion fruit plant.

The tests made it possible to observe the changeability in the antigonistic ability of the isolates. The Ti 2. Ti 17 and Ti 25 isolates of the T. koningii and the T-25 isolate of the T. har:ianum presented the bestperformances in antagonism to $C$. glocosporioides. The high level of intraspecilic variability which can occur was emphasised by Bell e't al.. (6).
Table 4.- Survival of $C$. glocesporioides after paired culture with Trichoderma (Ti) .

\begin{tabular}{|c|c|c|}
\hline \multicolumn{3}{|c|}{ Survival of C. glocosporioides isolatc (\%)' } \\
\hline Isolate & 7 days & 14 days \\
\hline Til & () & () \\
\hline $\mathrm{Ti} 2$ & () & () \\
\hline Ti.3 & 100 & 100 \\
\hline Ti5 & 100 & $\underline{1}(00$ \\
\hline Ti⿱ & () & () \\
\hline Ti9) & 4) & 100 \\
\hline Tilo & $10(0)$ & $I 00$ \\
\hline Tils & () & () \\
\hline Tils & () & () \\
\hline Till & () & () \\
\hline Tils & 20) & 100 \\
\hline Tile & () & () \\
\hline Ti25 & () & () \\
\hline Ti26 & 10() & 100 \\
\hline Ti.35 & 100 & 100 \\
\hline TR2 & () & () \\
\hline $\mathrm{T}-25$ & () & () \\
\hline
\end{tabular}

1). Awerige of these repetitions.

The variation in the ability of $T$. koningii in biocontrol has already becn observed ( +8$)$, the Ti 17 isolate was the one which showed the greatest number of characteristics desirable for use in biocontrol. having rapid growth. overlap capability, coiling around the phytopathogen hy phac with the formation of hook-hyphac. induction of plasmolysis and racuolation of hyphae and deformation of appressoria. T. konningii has becn cited as a biocontrol agent of many phytopathogens (38. 39. 4). 41 . $48)$. It produces a variety of antifungal metabolites. including antibiotics (3. 7, 19, 39, 41,48 ) and enzymes which degrade the cell wall (12).

A better understanding of the factors which affect the interactions between species of Trichoderma and $C$. glocesporioides. is necessiry for the development of an effective programme for the biological control of anthracnose in passion-fruit. In vitro tests in artificial media have the adrantige of speed and control of the factors investigated. but are shown to be derivated from ficld tests results in situr. A good performance in in vitro tests does not gutrantee that the isolate selected will have the same performance in the field. where many enviromental factors may influence the behaviour of the isolatc and alter its antagonistic capacity. Nerertheless, in 
vitro Iests are necessary for a preliminary understanding of the basic action methods of the fungus. kecping in mind the obvius limitations imposed by the artificial conditions in which the sludy has been undertaken (2.6.25. 27).

\section{ACKNOWLEDGMENTS}

We thank Sidney Turyassu Gomes Bastos and José Soarcs Silva Filho, for their helpful comments and suggestions that improved the manuscript.

\section{REFERENCES}

1.- Abdel Moity, T. II Papavizas, (;. C \& Shatla, MI. N.(1982). Induction of new isolates the Trichoderma harzianum tolerant to fungici-des and their experimental use for control of white rot in onion. Phrtopatholegy. St. Paul, 72: 396-4()()

2.- Andrews, J. II..(1992). The strening of microrganisms antagonistic

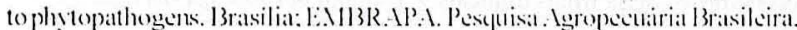
$27: 165-174$

3.- Augustinuak, II.; Forche, li..; Reichenhach, Il.; Wrav, V.; (irafe, I's

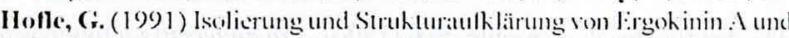
B: Zwei nete antilungische Sterol-antihiotika aus Fric/holerma konimgii Leiligs Ann. Chem: 361-366.

4.- Barnett, II. I. \& Binder, I. I. (197.3). The fingal hesi-parasite relationship. Ann. Rex: Plụtopathology: P'alo. N/to. 11:27.3-292

5.- Bastos, C.. N. (1991).Possibilidade do controle biologico da vassourat-

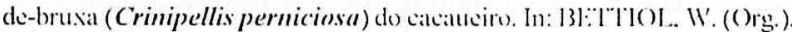

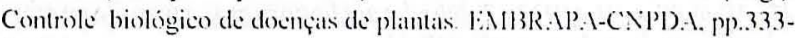
344

6.- Bell, I). K; W(Ils, II. I) \& Markham, C. R. (19\$2). "In vitro"antagenism

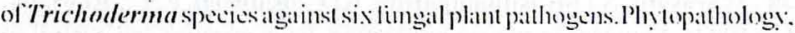
$72: 379-382$

7.- Benoni, II.; Taraz, K.; Kurth, H.\& Pulverer, (. (19)(1)).

Characterization of $6-p$ entyl-at-pyrons lirom the suil lingus Trichoderma koningii. Naturwissenschalien 77:5.39-540

8.- I3ettiol, W. \& (ihini. R. (1995). Controle bioligico. Ciạ). 36. In:Bergimin Fillo, A.: Kimati. H. \& Amorim. 1. (lids.). M:mual de lïtopatologia, Sà̃o Paulo: Agronomica: Cisces. pr. 717.727

9.- Blakioman .J. P. \& Folikema, N. J. (19\$2). Polencial lin biologicial control of plant diseases on the phelloplanc. Ann. Rev. Photopallhologs: 20:167-192

10.- Brian, P. W; Curtis, P. .J.; IIcmuning, II.C. \& Mc(iman, J.C: (1946). The productionol viridinby pigment-liomingstrainsol Trichoderma viride. Ann. App. Biology 3.3:19()-20()

11.- Chet, I. \& Baker, K. (I9S1).Isolittion e hiocontrol potencial of Trichoderma hamatum from soil naturally supressice lo Rhizoctomia solani. Plı̣topathology: 71:286-200)

12.- Chet, I. (1987). Trichoderma-ipplication. mode of atction. and potential as a biocontrol agent ol soilborne plant pathogenic lingi. In: C'let. I Innovative Approathes to Plant D)isease (ontrol sed. Jonh Wiley de Sons. New Fork. pl. 1.37-160

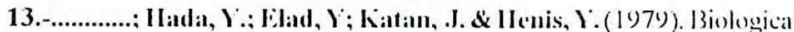
control of soil borme plant pathugens by Tricholerma har siamum. In:

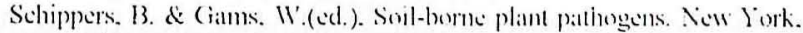
Academic Press. pro $585-592$

14.- Cook, R. J. \& Batier, K.l. (I)\&י). The nature and pratice of biological control of plant pathogens. St. l'aul: . APS' l'ress.
15. (1993). Making greater useol introduced microotganism for biological control of plant patlogens. Ann. Rev. Phytopathol. 31:53-80 16.- Dennis, (.. J. \& Webster, J. (1971a). Antagonism properties of species-groups of Trichoderma, I. Production of non-volatile antibiotic: Trans. British mucol. Socicty 57:25-39

17. (19716)..Antagonism properties of species-groups of Tricholerma. II. Production of volatile antibiotic. Trans. British micol. Societs: 57:-11-48

18.(1971c). Antagonism properties of species- groups of Tricholerma. III.IIyphal interatetion. Trans. British micul. Socicts 57:363-369)

19.- Dunlop, R. W.; Simon, A. \& Sivasithamparam, K. (1989). An antihintic liom Trichoderma koningii active against soilborne plant pathugens. J. Nat. Prod. 52: 67-74

20.- lilad, V., C.het, I. \& Katan, .J. (1980). Trichoderma harzianum: a biocontrol agent sllitive against Sclerotium rolfsii and Rhizoctonia soltani. P’hycopathology. St. Paul 70:111)-21

21.- Lad, Y.; Sadowsky, Z. \& (Thet, I. (1987). Scauning electron microscopical observations of early stages of interation of Trichoderma har:ianum and Rhizoctonia solani. Trans. Br. Mycol. Soc. 88: 259-263

22.- Limmett, R.W. \& Parbery, D.(. (1975). Apressoria. Amn. Rev Phỵtopathollogy 13: 1+7-167

23.- Fernandes, .J. C..; Cumha, II. \& Santos, J. C. (1990). Omercado de maracujia na (K.AS.A-R.J. principatis anpectos 1989. Niteroi: Pesagro - Rio. Siric documentes. n"20. 20p

24.- Freeman, T. F. (19\&1). ['se ol conidial tungi in biological control. In: Cole. (i.T. \& Kendrick. 13. Biology of conidial fungi. Academic Press. I.ondon, 2:14.3-6.5

25.- (ioldfarb, B.; Nelson, V.. E.. \& IIansen, E.M. (1989). Trichoderma spp).: (irmwth rates and antiggnism to Phellinns weirii in vitro. Mycologia. $81: 375-381$

26.- Harman, (i.li.; C.het, I. \& Bakcer, R. (1981).Factors allecting Trichoderma hamatum applied to seeds as a biocontrol agent. Phọtopathologe: Sit. Patul. 71:569-572

27.- IItumcehin, M. (1987). Potencial s emprego de isolados brasileiros de Tricholerma harziammm Rilai, para controle de patógenos de soja [Cily cine max (I..) Meiril.]. Tese de doutorado, E. S. A. "L uniz de Queiroz". 186 pp. P'iracicabal. Sìo l'aulo.

28.- Ilou, C: T.; Ciegler, A. \& IIesseltine, C : W. (1972). New mycotoxin trichotoxin . A. liom Trichoderma viride isolated firom Southern leal blightinlickd eorn. Appl. Microbiology: 23: 183-185

29.- Jeftries, P. \& Koomen, I. (1992). Strategies and prospects for biological control of discasess catised by Colletotric/hum. In: Bailey. J.A. \& 
Jeger. M.J. (Eds.). 1991. Colletotrichum: Biology. pathology and control. C.AB Internacional. Waallingford. UK. p.3.37-357

30.- Lilly, V. G. \& Barnett, II. L. (1951). (irowth. In: L.illy: V. G. \& Barnett. H. L. Physiology of the fungi. New lork: Me(iraw-Ilill Book Company. cap. 3. p. 24-44

31.- Lima, M. F. (1996). Trichoderma spp). antagonistats de Fiasarium oxisporum fi. sp. passiplorae en plantios de maracujaksiros em triss perimetros irrigados do vale do Suh-medio Sĩo Francisco. Anais do V Simpresio de Controle Biologico. Fơ do lgguaçủ. Paranai

32.- Manica, I. (1981). Fruticultura Tropical: Maracujia. Sĩo Paulo: CERES, 160)

33.- Medeiros, S. A. F. (1988). Mlicroflera da liolhagem do cajueiro. Anacardium occidentale $\mathrm{I}$... 2 controle bioligioo do agente da antratenosc. Colletotrichum gloeosporiovides (Penz..) Satce.. "in vitro". Dissertaçĩo de mestrado. LI:RPl:

34.- Mclo, I.S. (1991). Polecialidade de utilizaļ̧ão de Trichoderma spp) no controle biologico de doenç̧als de plantias. In: 13entiol. W'. (org.). Controle biológico de doenç̧as de plantas. EAIIBR.AP.A-(NPI) A. p.333-344

35.- Papavizas, (i.C.:(1985). Trichoderma c Gilincladium: Biology. «ology, and potencial fior biocontrol. Ann. Rer. Phatepathologe: 23:23-54

36.- Prezotti, J. C. G de O.; Tavares, S. C . C. de II. \& Peixoto, A. R. (1995). Ocorrincia natural de Trichoderma spp. sobre liusarium spp.. agente catusal da murcha do maracujiaciro. no sub-medio São lrancisces. Fitopatologia Brasilcira.

i.

37.- Ritzinger, R. (1984). Fefeito do expaçannento de plantió sobtre a produção e qualidade dos frutos de maracuja amnarelo (P'assiflora edulis f. flavicarpa Deg.) Porto Alegre: tese. F Al il:12(is

38.- Simon, A. \& Sivasithamparam, K. (19א8). Interations among Gatemannomyces graminis var. tritici. Trichoderma koningii. and soil bacteria. Cam. I. Microbiol. 34: 871-876

39.- Simon, A. \& Sivasithamparam, K. (1989). Pathogen-suppression: A calse study in hiological suppression of (iacumanmmupes graminis var. trifici in suil. Soil J3iol. Biochem. 21: 331-337

4(1).Simon, A. (1989). Biological entrol of take-all of wheat by Trichoderma komingii under controlled envirommental eonditions. Soil Biol. 13iochem. 21: 323-326

41.- Simon, A.; Dunlop, R.W.; ( Shisalbert, F.L. \& Sivasithamparam, K. (1988). Trichoderma koningii produces a pyrone compound with antihiotic propertics. Soil 13iol. 13iochem. 20:263-264

42.- Tabachuik, M. (198S). Trichoderma : production and formulation. Triohoderma Newskller. n"t

43. - T'eixcira, ( . ( de Nlimentos. Maracujia. Cultura, matcria-prima, processamento aspectos econsmicos. Siric firuts tropicatis 9. Campinas. 1995. p.1-1.31

44.-Tronsmo, A. \& Demnis, C.. (1978). V:llict of temperature on antagonistic propertiesol Trichoderma species. Trans. British. Mycol. Soc. 71:469-474

45.- Trutmam, P. \& Keane, P.J. (19)()). Trichoderma komingii as a biologial control agent lor Sclerotinia sclerotiorum in Southern Australia. Soil. Biology and Bischemistry 22: $4.3-5(1$

anc liom the culture filtratc of Trichoderma. Phytopathology 26:1068-

46.- Weindling, R. \& Emerson, II. (1936). The isolation of a toxic substance firom the culture filtrate ol Trichoderma. Photopathology 26:10681070

47.- Weindling, R. (1932). Trichoderma lignorum as a parasite on other soil fungi. Phỵtopathology: 22: $837-45$

48.- Worasatit, N.; Sivasithamparam, K; Cihisalberti, J. I.; Rowland, (x. (19i)4). Variation in pvrone production. Istic enzmes and control of Rhizoctomia rout rot of wheat among single-spore isolates of Trichoderma koningii. Mycol. Res. 98:1357-1363

49.- Yamashiro, T. (1987). Principais doençats do maracujazeiro amarelo no Brasil. In:Ruggiero, C: Maracuja. Ribsirĩo Preto, Legis Summa, 1987. p. $146-59$ 